\title{
An attempt to improve the proximate composition of local Artemia strain (Wadi El Natrun, Egypt)
}

\author{
El-Sayed T. Rizk ${ }^{1 *}$, Fayez A. Shoukr ${ }^{1}$, Mona M. El-Gamal ${ }^{1}$, Fatma A. Abdel-Razek² and Mahy M. Mona ${ }^{1}$
}

\begin{abstract}
Background: Comparative analysis of essential amino acids and fatty acid of enriched and unenriched Artemia spp. collected from Wadi El Natrun, Elbeheira, Egypt, was investigated.

Results: The obtained results indicated that Leucine recorded the highest concentration $(17.22 \%, 11.4 \%)$ in unenrichment $A$. tunisiana and $A$. franciscana, respectively followed by arginine $(10.31 \%, 9.6 \%)$; however, glutamic acid recorded the lowest concentration (0.05\%) in A. tunisiana. Statistical analysis showed no significant differences in some amino acid concentrations $(P<0.001)$ in both $A$. tunisiana and $A$. franciscana as arginine, valine, proline, and aspartic acid. Other amino acids were highly significantly fluctuated as glycine, leucine, histidine, phenylalanine, glutamic, and tyrosine; they were high in A. franciscana. Aspartic acid was significantly higher in unenrichment nauplii. Regarding the comparison between A. franciscana and enrichment A. tunisiana, the data showed non-significant improvement for the majority of the recorded amino acids. The analysis of unsaturated fatty acids n-3 and n- 6 families after 18 and $24 \mathrm{~h}$ of enrichment Artemia was achieved. The composition of unsaturated fatty acids was significantly increased after enrichment to $79.7 \mathrm{mg} / \mathrm{g}$ DW instead of 46.5 in newly hatched nauplii. Saturated fatty acids were also significantly increased from 20 to $25.28 \mathrm{mg} / \mathrm{g}$ DW. The enrichment process was significant $(P<0.001)$ in nauplii enriched with fatty acids for $18 \mathrm{~h}$. The more pronounced effect of duration was the amount of energy as it was $33.17 \mathrm{~kJ} / \mathrm{g}$ after $18 \mathrm{~h}$, while it was $45.693 \mathrm{~kJ} / \mathrm{g}$ after $24 \mathrm{~h}$ incubation. The ratio of ascorbic acid, due to Artemia enrichment by vitamin $\mathrm{C}$ for $24 \mathrm{~h}$, was increased from 853 to $3227 \mu \mathrm{g} / \mathrm{g}$ dry weight after enrichment.
\end{abstract}

Conclusion: To conclude, enrichment with cod liver oil and vitamin C obviously affected the chemical composition of local Egyptian Artemia (A. tunisiana).

Keywords: Artemia, Fatty acids, Amino acids, Enrichment, Vitamin C

\section{Background}

Artemia is a cosmopolitan crustacean that has established itself worldwide in a harsh saline aquatic environment and gained a unique position in aquaculture system since it has several characteristics such as easy to handle, adaptable to wide environmental condition, non-selective filter feeder, and capable of growing at very high densities (Sivaji, 2016). Moreover, its high nutritive value meets both the dimensional (in terms of prey size) and nutritional requirements for the fish or finfish larva (Lubzens, Tandler, \& Minkoff, 1989). The nutritional value of

\footnotetext{
* Correspondence: rizktaha@yahoo.com

'Zoology Department, Faculty of Science, Tanta University, Tanta, Egypt Full list of author information is available at the end of the article
}

Artemia can be improved by the enrichment process, thereby incorporating fatty acids and other compounds (vitamins, minerals, and antibiotics) into the larval rearing protocols.

Artemia strains from different geographical origins vary considerably in their nutritive values (Heydari \& Akbary, 2011). These variations may have great influence on survival and growth of cultured fish and crustaceans (Salma, Davoodi, Shamsaei, \& Kamali, 2013). Japanese, American, and European researchers studied these problems, and they confirmed variations in the nutritional value when using different geographical sources of Artemia for fish and shrimp species (Leger, NaessensFoucquaert, \& Sorgeloos, 1987). The situation became more critical when very significant differences in 
production yields were obtained with distinct batches of the same geographical origin of Artemia (Robin, Le Milinaire, \& Stephan, 1987). The important factor affecting the nutritional value of Artemia as food source for marine larval organisms is their contents of essential fatty acids, eicosapentaenoic acid (EPA, 20:5 n-3), and even more importantly docosahexaenoic acid (DHA, 22: $6 \mathrm{n}-3)$. In contrast to freshwater species, most marine organisms do not have the capacity to biosynthesize EPA from lower chain unsaturated fatty acids (Robin et al., 1987; Van Stappen, 1996).

Leger et al. (1986) and Robin et al. (1987) summarized the advantages of Artemia enrichment as they have higher energy content and contain all essential fatty acids $n-3$, which is generally absent in nauplii from all strains. Through enrichment techniques, other nutrients, prophylactics, and therapeutics may pass to predators via Artemia nauplii. Larvae fed on enriched Artemia are indeed healthier and more resistant to stressful conditions such as infections and weaning of fish, when transferring post larvae from hatchery tanks to nursery ponds.

Exploitation of Artemia in Egypt was started when Abdel Rahman and Abdel Razek (1992), Abdel Rahman (1993, 1994) evaluate some of local Artemia resources. In the same interval, by the help of FAO agency surveyed natural Egyptian Artemia from different sites; most of these sites are manmade salinas located on the Mediterranean coast, while only two sites are located in inland areas. The coastal sites are Port-Fouad, Balteim, El Max, and Bourg El Arab Salinas, while the inland sites are Wadi El Natrun and Fayom salina beside Qaroun Lake. Crossbreeding tests revealed that Artemia from Wadi El Natrun is belonging to Artemia tunisiana. The investigation completed by FAO (1994) established that the production of Artemia in Egypt is technically and economically feasible when A. franciscana has been inoculated in Port Fouad salina.

The main target of this paper was to investigate the effect of enrichment with cod liver oil and vitamin $C$ on the chemical composition of local Egyptian Artemia (A. tunisiana) which has some deficiencies in order to introduce superior species to battle the imported ones and finally grow to be a successful economic activity.

\section{Methods}

\section{Enrichment of Artemia tunisiana}

This experiment was done in two labs; the enrichment part was done in the Central laboratory, Zoology Department, Faculty of Science, Tanta University, Egypt, and the biochemical analysis was done in the National Institute of Oceanography and Fisheries Central Laboratories Unit, Alexandria, Egypt. The dried cysts of the brine shrimp Artemia franciscana were obtained from King British Aquarium Accessories Co Ltd., Bradford, UK, while local Artemia cysts (A. tunisiana) were collected from El Hamra Lake, Wadi El Natrun, Elbereira, Egypt.

\section{Culture conditions}

Both strains were hatched following standard procedures (Sorgeloos et al. 2001). Newly hatched Artemia nauplii (stage 0) $(200,000$ nauplii/l) were divided in batches in 5-l tanks. Enrichment protocol followed the method of Treece (2000). Briefly, $0.5 \mathrm{ml}$ of the enrichment emulsion (assuming a density of 200 Artemia per ml) was added per liter of the incubation water at the onset of the enrichment period. Newly hatched Artemia nauplii served as the control. The enrichment medium maintained at $25 \pm 2{ }^{\circ} \mathrm{C}$. The enrichment emulsion was added at a dose of $0.5 \mathrm{~g} / \mathrm{l}$ that was applied at two time intervals: after hatching and $18 \mathrm{~h}$ post hatching. Strong aeration was applied to maintain dissolved oxygen levels above $4 \mathrm{mg} / \mathrm{l}$. Enrichment nauplii were harvested at $18 \mathrm{~h}$ and $24 \mathrm{~h}$ post hatching. The harvested samples were divided into three groups: group 1 for weighing, group 2 for measuring length, and group 3 for thoroughly rinsed and stored at temperatures below $10{ }^{\circ} \mathrm{C}$ in order to assure that highly unsaturated fatty acids (HUFAs) are not metabolized during storage. These samples were later used for further analysis.

\section{Standard method for enrichment of Artemia nauplii with vitamin C}

Enrichment with vitamin $C$ is the second step to enrichment with HUFAs. Therefore, in order to enrich the live food with vitamins, fatty acid emulsion was used as carrier of this component. Fatty acid emulsion was prepared and $10 \%$ of Ascorbyl palmitate $w / w$ was added to the fatty acid emulsion (Treece, 2000). Mixing was done using an electric mixer until the vitamin $\mathrm{C}$ is dissolved. The emulsion containing vitamin $\mathrm{C}$ was preserved in refrigerator until use. Nauplii were enriched with two doses of this mixture at 0 and $18 \mathrm{~h}$ during the process of enrichment.

\section{Sample analysis}

\section{Proximate composition}

Moisture, crude protein, crude lipid, and ash were measured using standard methods (Association of Official Analytical Chemists (AOAC), 1990).

\section{Moisture}

Moisture was determined by placing a thin layer of Artemia of known weight in an aluminum pan, and then placed in a drying oven at $90{ }^{\circ} \mathrm{C}$. Samples were removed after $24 \mathrm{~h}$, placed in a desiccator for $30 \mathrm{~min}$ to cool 
down, and weighed. This procedure was repeated every $2 \mathrm{~h}$ until a constant weight was reached.

\section{Protein content}

Total organic nitrogen was determined by the Kjeldhal method.

\section{Total lipids}

Lipid extraction and analysis were performed using the Soxtec system, which is a modification of the Soxhlet principle. Crude freeze-dried samples were ground to a fine powder, weighed (approximately $3.0 \mathrm{~g}$ ), placed in extraction thimbles, covered with cotton wool, and inserted in the Soxtec machine. Pre-weighed extraction cups with boiling chips and approximately $25-50 \mathrm{ml}$ of hexane were also placed in the Soxtec system. Extraction was performed for $60 \mathrm{~min}$ in the "Boiling" position and, subsequently, for 30-45 min in the "Rinsing" position. After evaporation of the solvent, extraction cups were placed in the drying oven (at $100{ }^{\circ} \mathrm{C}$ ) for $30 \mathrm{~min}$. Cups were cooled in a desiccator and weighed. Crude fat could then be calculated as shown by Goddard (1992).

\section{Ash}

Crucibles were first washed, dried, incinerated $\left(550{ }^{\circ} \mathrm{C}\right.$ for $2 \mathrm{~h}$ ), cooled in desiccator, and weighed. Samples were added to crucibles, weighed, and placed in a muffle furnace $\left(250{ }^{\circ} \mathrm{C}\right.$ for $\left.2 \mathrm{~h}\right)$. Temperature was then raised to $550{ }^{\circ} \mathrm{C}$ and samples were left overnight. After cooling in a desiccator, crucibles with samples were again weighed and ash content calculated.

\section{Carbohydrates}

This group of nutrients-e.g., sugars and starches-was estimated as the difference between the sum of the other constituents and the original dry weight of the sample.

\section{Amino acid analysis}

Total amino acids Total amino acids were determined as described by Shahidi et al. (1990) and Blackbum (1978).

\section{Free amino acids}

For determination of free amino acids, freeze-dried samples were homogenized using a Polytron PT 3000 (Brinkmann Instruments, Rexdale) homogenizer in a small 50-ml centrifuge tube with $20 \mathrm{ml}$ of ice-cold $6 \%$ perchloric acid for $2 \mathrm{~min}$ in an ice bath (Yamanaka, 1989).

\section{Fatty acid analysis}

Fatty acid composition of lipids was determined using gas chromatography (GC). Lipids were extracted with chloroform and methanol, based on the method described by Bligh and Dyer (1959).

\section{Statistical analysis}

All results were represented as mean \pm SE $(n=3)$. Statistical comparisons between groups were made using a one-way analysis of variance (ANOVA) as part of an SPSS and a post hoc test followed by Dunnett's multiple comparison tests. All $p$ values were paired two-tailed, with $p$ values $<0.05$ considered significant.

\section{Results}

\section{Proximate composition}

The average proximate composition (in \% dry basis) in milligrams per gram DW of the newly hatched Artemia tunisiana; Borg El Arab, El Mex, and Port Saied strains; and the imported American strain (A. franciscana) are shown in Table 1. The results showed that the Port Saied strain had the highest lipid composition followed by $A$. franciscana while the lowest lipid composition was scored by A. tunisiana. No differences were recorded in protein content in Artemia collected from the Wadi El Natrun, Borg El Arab, and San Francisco Bay strains. On the other side, the Port Saied strain had the highest protein content followed by El Mex. No differences in carbohydrate composition from all strains $(\sim 14 \%)$ except for Port Saied, it recorded $10.8 \%$. The fiber content in both Port Saied and A. franciscana had the lowest values (4.9 and 3.7\%, respectively) and decreased than the rest of the strains.

In the case of enrichment of A. tunisiana as shown in Fig. 1 , the more noticeable elevated component was the lipid which increased to $21.53 \%$ after $24 \mathrm{~h}$ from enrichment process. The proximate composition of ash, carbohydrate, and fibers were significantly decreased in enrichment samples while the moisture ratio was significantly increased $(p<0.05)$.

\section{Amino acid composition}

Table 2 summarizes the free amino acids of unenrichment and enrichment $(24 \mathrm{~h})$ A. tunisiana comparable with $A$. franciscana as gram of amino acid per $100 \mathrm{~g}$ of protein in the sample. Leucine recorded the highest concentration (17.22 and 11.4\%) in unenrichment $A$. tunisiana and $A$. franciscana respectively followed by arginine (10.31 and 9.6\%). The lowest amino acid was glutamic acid $(0.05 \%)$ and recorded with $A$. tunisiana. One-way ANOVA analysis shows non-significant differences in some amino acid concentration $(p<0.05)$ in both $A$. tunisiana and $A$. franciscana as arginine, valine, proline, and aspartic acid. While others were highly significantly fluctuated as glycine, leucine, histidine, phenylalanine, glutamic, and tyrosine, they were high in A. franciscana. As demonstrated in Table 2, some amino 
Table 1 Average proximate composition (in \% dry basis) mg/g DW of the newly hatched different Artemia strains

\begin{tabular}{|c|c|c|c|c|c|c|c|}
\hline Strain & Moisture & Ash & Protein & lipid & Carbohydrate & Fiber & Sum (\%) \\
\hline A. tunisiana & 64.3 & 7.54 & 54.46 & 12.59 & 13.8 & 8.71 & 97.1 \\
\hline Borg El Arab & 69.52 & 5.27 & 53.81 & 13.96 & 14.18 & 8.21 & 95.43 \\
\hline El Mex & 72.16 & 6.43 & 56.17 & 14.4 & 13.6 & 8.5 & 99.1 \\
\hline Port Saied & 70.25 & 7.67 & 57.8 & 16.86 & 10.82 & 4.9 & 98.05 \\
\hline A. franciscana & 63.8 & 7.11 & 53.5 & 15.7 & 13.7 & 3.7 & 98.76 \\
\hline
\end{tabular}

acids were not affected by enrichment as arginine, glycine, valine, proline, and leucine. Others were affected; they were significantly higher as histidine, phenylalanine, glutamic, and tyrosine. In the case of aspartic acid, it was significantly higher in unenrichment nauplii. Regarding to the comparison between $A$. franciscana and enrichment $A$. tunisiana, the data showed nonsignificant improvement for the majority of the recorded amino acids.

\section{Fatty acid composition and the effect of enrichment duration (18-24 h)}

As demonstrated in Fig. 2, higher amounts of total essential fatty acids in the $n-3$ and $n-6$ families after 18 and $24 \mathrm{~h}$ of enrichment were achieved, for example, 18:2 $\omega-6$ (linoleic acid), 18:3 $\omega-3$ (linolenic acid), 18:4 $\omega-3$ (octadecatetraenoic acid), 20:3 $\omega-3$ (eicosatrienoic acid) beside 20:5 $\omega-3$ (eicosapentaenoic acid) and 22:6 $\omega-3$ (docosahexaenoic acid). The composition of unsaturated fatty acids was significantly increased after enrichment to $79.7 \mathrm{mg} / \mathrm{g} \mathrm{DW}$ instead of 46.5 in newly hatched nauplii. Saturated fatty acids were also significantly increased from 20 to $25.28 \mathrm{mg} / \mathrm{g}$ DW.

As the fatty acids were taken up by Artemia, their profiles changed according to the duration of the enrichment period from 0 to $18 \mathrm{~h}$ in Fig. 2. The enrichment process as depicted in Fig. 2 was significant $(P<0.001)$ in nauplii enrichment with fatty acids for $18 \mathrm{~h}$, while the fatty acid composition was not significantly different due to the duration from 18 to $24 \mathrm{~h}$, except for the two fatty acids 18:2 $\omega-6$ and 18:3 $\omega-3$. Newly hatched Artemia had $64 \mathrm{mg}$ total fatty acids/g dry weight with no detectable levels of DHA (22:6 $\omega-3)$. After enrichment for $18 \mathrm{~h}$, the total fatty acids increased significantly to $97 \mathrm{mg} / \mathrm{g}$, then elevated to $112 \mathrm{mg} / \mathrm{g}$ dry weight after $24 \mathrm{~h}$. The level of DHA in Artemia was significantly increased to reach $1.45 \mathrm{mg} / \mathrm{g}$ after $18 \mathrm{~h}$, while another beak was noted $(1.86 \mathrm{mg} / \mathrm{g})$ after $24 \mathrm{~h}$. The second important fatty acid (EPA) reached $8.13 \mathrm{mg} / \mathrm{g}$ DW after $24 \mathrm{~h}$; it was $1.3 \mathrm{mg} / \mathrm{g}$ in unenrichment nauplii. The highest fatty acid was 18:1 $\omega-9$ (oleic acid), it was 35 . $85 \mathrm{mg} / \mathrm{g}$, followed by palmatic acid (16:0) which was 16 . $3 \mathrm{mg} / \mathrm{g}$ DW, then $18: 3 \omega-3(13.46 \mathrm{mg} / \mathrm{g}$ DW) after $24 \mathrm{~h}$ of enrichment. The lowest fatty acid concentration was 14:0 (myristic acid) and did not change by $18 \mathrm{~h}$ enrichment, while slightly increased after $24 \mathrm{~h}$ of enrichment. When comparing the fatty acid composition between Artemia franciscana and tunisiana nauplii, the result as shown in Fig. 2 showed that there were significant differences between fatty acid composition between both species without enrichment; it was higher in A. franciscana

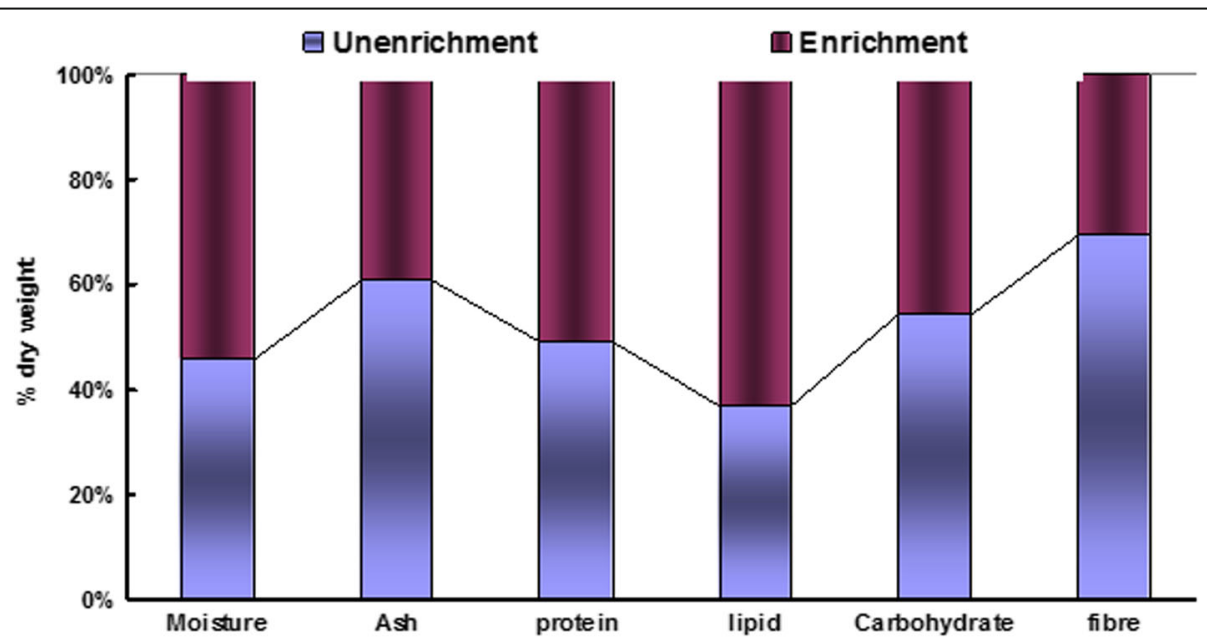

Fig. 1 Biochemical composition (\% dry weight) in newly hatched (unenrichment) and enrichment (24 h) Artemia tunisiana nauplii 
Table 2 Amino acid composition (g amino acids/100 g) (\% dry basis) of $A$. franciscana (A) and unenriched Artemia tunisiana (B), and enriched with HUFA + vitamin C (C) for $24 \mathrm{~h}$

\begin{tabular}{llll}
\hline Amino acids & $\begin{array}{l}\text { A. } \\
\text { franciscana } \\
\text { (A) }\end{array}$ & A.tunisiana & \\
\cline { 4 - 4 } & 9.6 & 10.31 & 10.75 \\
\hline Arginine & 4.3 & 1.7 & 2.04 \\
Glycine & 6.31 & 6.41 & 5.7 \\
Valine & 5 & 5.10 & 7.21 \\
Proline & 11.4 & 17.22 & 14.8 \\
Leucine & 2.7 & 1.04 & 3.11 \\
Histidine & 8.6 & 2.49 & 4.76 \\
Phenylalanine & 9.76 & 0.05 & 1.5 \\
Glutamic acid & 9.3 & 9.8 & 4.31 \\
Aspartic acid & 4.6 & 0.36 & 2.8 \\
Tyrosine & & &
\end{tabular}

especially with 18:0, 18:1 $\omega-9,18: 3 \omega-3$, and 20:5 $\omega-3$. Concerning enrichment, the results were opposite where A. tunisiana scored a highly significant increase in fatty acid composition except for 14:0, 16:0, and 18:1 $\omega-9$, and 18:3 $\omega-3$.

From Table 3, it can be seen that all of the enrichment procedures listed result in significant increases in total fatty acids compared to newly hatched Artemia nauplii except for 6:0. An increase in the total fatty acids equates to an increase in the caloric value of the feed (i. e., increase in energy content from 23.050 to $45.693 \mathrm{~kJ} /$ g). The essential highly unsaturated fatty acids (HUFAs) 20:5 n-3 or eicosapentaenoate (EPA) and 22:6n-3 or docosahexaenoate (DHA) are significantly higher in Artemia nauplii that have been enriched.

Table 3 assumes the effect of enrichment duration on some parameters. There was no effect of duration on
Table 3 Average total protein, lipid (\% DW), DHA, and EPA fatty acid composition (mg/g DW) and DHA:EPA ratios in control and enriched Artemia tunisiana at 18 and $24 \mathrm{~h}$

\begin{tabular}{llll}
\hline Parameters & Unenriched & Enriched & \\
\hline Time (hours) & 0 & 18 & 24 \\
Protein & 54.46 & 57.3 & 57.8 \\
Lipid & 12.59 & 21.53 & 22.29 \\
Protein/lipids & 4.326 & 3.03 & 2.68 \\
C22:6n3 (DHA) & 0 & 1.45 & 1.86 \\
C20:5n3 (EPA) & 1.3 & 7.62 & 8.13 \\
DHA/EPA & 0 & 0.19 & 0.23 \\
\hline
\end{tabular}

total protein or lipid concentration Fig. 3. A slight effect was noticed in the concentration of DHA and EPA fatty acids as illustrated in Fig. 4. On the other area, the length and stages were affected, for instance, $100 \%$ of nauplii achieved stage (1) after $18 \mathrm{~h}$ from incubation, while after $24 \mathrm{~h} 37 \%$ reached stage (2). The length also was changed from $574 \pm 85 \mu \mathrm{m}$ after $18 \mathrm{~h}$ from enrichment to $646 \pm 160 \mu \mathrm{m}$ after $24 \mathrm{~h}$ Fig. 5. The enrichment duration had no significant effect $(P<0.001)$ on the weight of the specimens. After $18 \mathrm{~h}$, it scored $2.79 \pm 0$. $083 \mu \mathrm{g}$ while after $24 \mathrm{~h}$ it gained only $0.04 \mu \mathrm{g} /$ individual. The more pronounced effect of duration was the amount of energy $(\mathrm{kJ} / \mathrm{g})$; as mentioned in Fig. 6, it was $33.17 \mathrm{~kJ} / \mathrm{g}$ after $18 \mathrm{~h}$, while it was $45.693 \mathrm{~kJ} / \mathrm{g}$ after $24 \mathrm{~h}$ from incubation.

\section{Ascorbic acid}

The ratio of ascorbic acid due to enrichment by vitamin C was increased from $15 \%$ (853 $\mu \mathrm{g} / \mathrm{g}$ dry weight) with newly hatched nauplii to $85 \%$ (3227 $\mu \mathrm{g} / \mathrm{g}$ dry weight) after enrichment for $24 \mathrm{~h}$ (Fig. 7). One-way ANOVA showed highly significant differences $(P<0.05)$ due to enrichment.

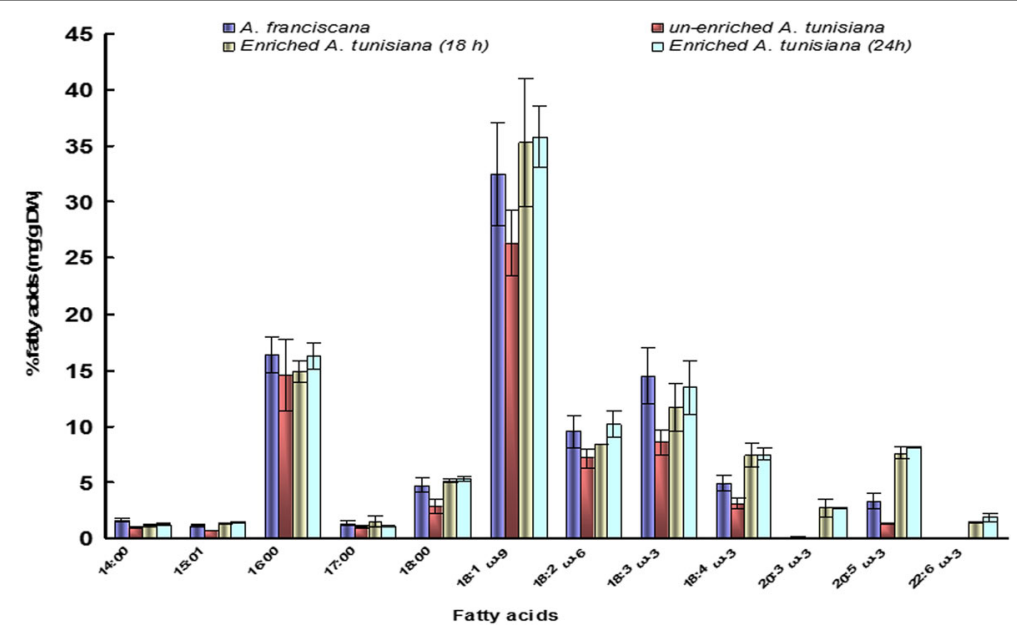

Fig. 2 Fatty acid composition of unenrichment A. franciscana, A. tunisiana, and enrichment A. tunisiana for 18 and $24 \mathrm{~h}$ 


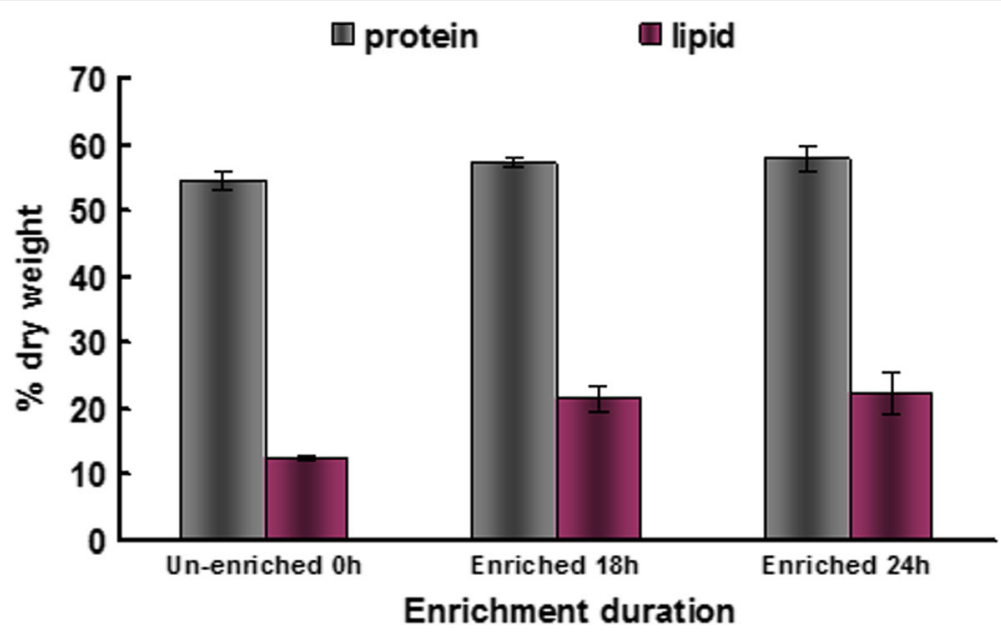

Fig. 3 Protein and lipid (\% dry weight) under different enrichment durations

\section{Discussion}

Egypt has varieties of Artemia strains that can be utilized for feeding of larval stages of different fish and crustacean species in hatcheries (Zaki \& Abdel Rahman, 1985; Abdel Rahman, 1995). Generally, the results of crude protein, ash, and carbohydrates were within the ranges compiled by Leger et al. (1986) from 15 references. Heydari and Akbary (2011) analyzed the proximate composition of Artemia from Urmia Lake, Iran, and they recorded values which resemble to those in $A$. tunisiana except for protein which was higher $(61.7 \%$ protein) while other proximate composition were nearly the same $(11.44 \%$ lipid and $6.78 \%$ ash on a dry weight basis). Ash content in all investigated strains (7.5, 5.2, 6 . 4, 7.6, and 7.11\%) for Artemia Wadi El Natrun, Borg El
Arab, El Mex, Port Saied, and San Francisco Bay strain respectively was analogous to the values (7.6 and 7.1\% Great Salt Lake Artemia) recorded by García-Ortega et al. (1998) and Estevez et al. (1998) and 8.17\% with San Francisco Bay (Han, Geurden, \& Sorgeloos, 2000). On the other hand, nauplii collected from PR China and France recorded high ash content of 21 and 15\% (Lavens, Léger, \& Sorgeloos, 1989). This is probably a consequence of the wild population's feeding regime which is mainly based on organic particulate matter that can cause ash accumulation in the digestive tube, thus increasing the ash proportion and lowering that of other nutritional elements (Gozalbo \& Amat, 1988).

Protein composition of all studied Artemia strains by Leger et al. (1986) ranged from 53.81 to $57.8 \%$. The

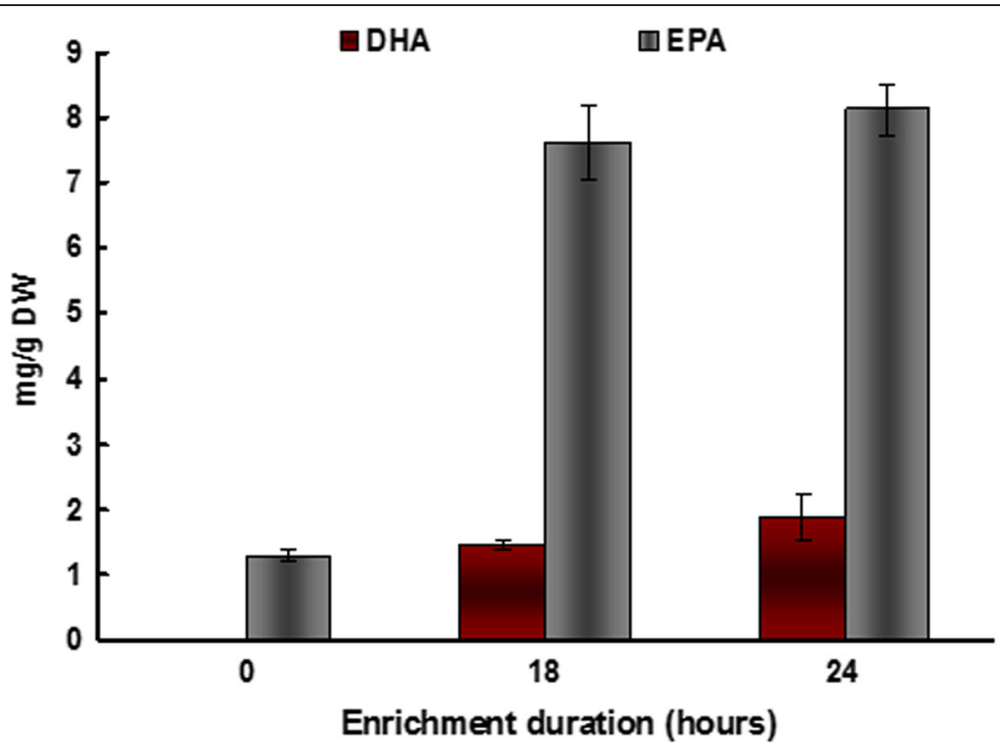

Fig. 4 EPA and DHA levels in Artemia nauplii under different enrichment durations 


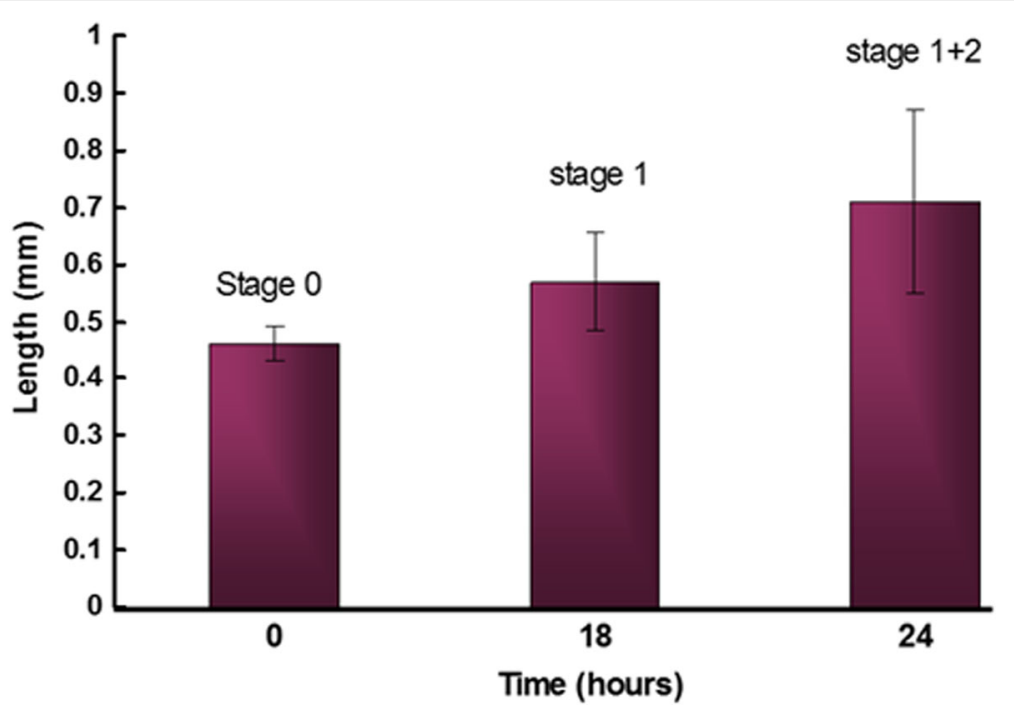

Fig. 5 Lengths and stages of A. tunisiana under the effect of enrichment duration. Stages are according to Weisz scheme (1946)

protein content in the same studied Egyptian strains (El Mex, Borg El Arab, and Port Saied) was measured before by Abdel Rahman (1995); he recorded nearly the same values (56.23-57.63\%) of the investigated strains. And also they were relatively similar to the other wild Artemia fed on rich protein sources such as Spirulina Maldonado-Montiel \& Rodriguez-Canche, 2005). The previous authors recorded 53,50, and 58\% protein for different Artemia strains fed on different protein sources. Comparable to A. franciscana, the Egyptian strain under the present study showed no significant differences between them (53.5\%); its protein content has been previously studied by many authors and was found to meet the essential requirement of many fish species (Claus, Benijts, Vandeputte, \& Gardner, 1979). Other studies with other strains recorded protein content of

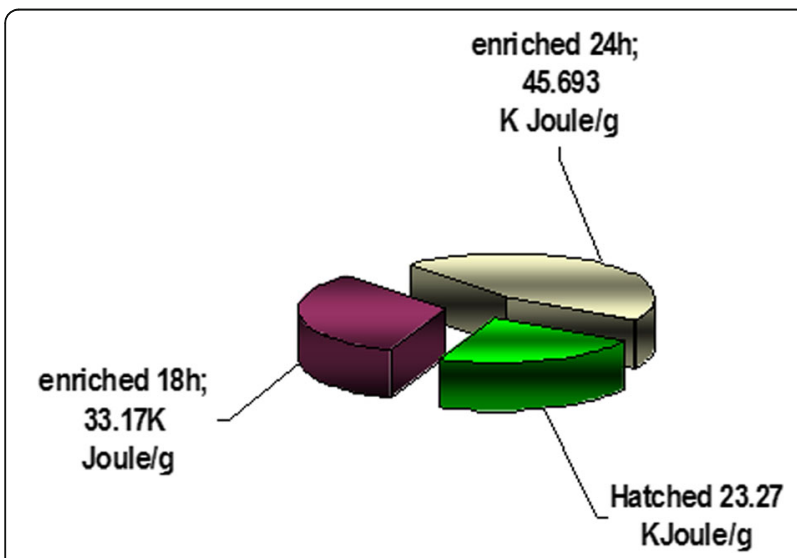

Fig. 6 The energy content $(\mathrm{kJ} / \mathrm{g})$ of enrichment A. tunisiana nauplii after 18 and $24 \mathrm{~h}$ from incubation
61, 56.2, and 54.03\% in nauplii from Great Salt Lake strain (García-Ortega et al., 1998; Moraiti-Ioannidou, Castritsi-Catharios, Miliou, \& Sorgeloos, 2009).

Some confusion appears when reviewing amino acid profile of Artemia because of different methods of analysis or reporting data. Leger et al. (1986) has suggested that other factors such as the developmental stages of the animals, population-based differences, and the type, quality, and quantity of food available can affect the amino acid composition in Artemia. Related to the present data, both A. tunisiana and A. franciscana nauplii contained sufficient levels of the 10 amino acids. Protein contents of $A$. tunisiana was not significantly different from that of $A$. franciscana strain; on the other side, the content of some amino acids as phenylalanine,

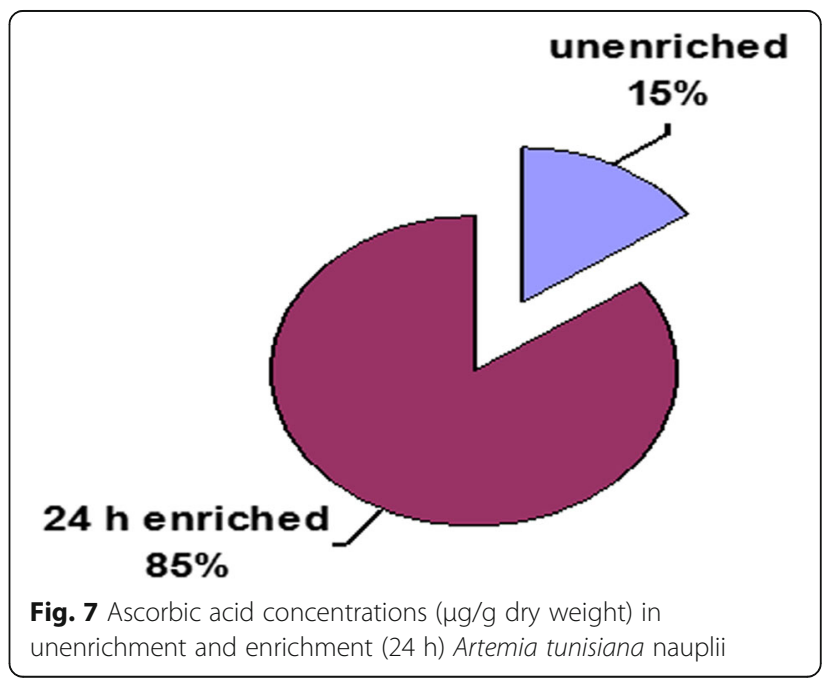


glutamic acid, and tyrosine were significantly higher in A. tunisiana. Abdel Rahman (1995) who accomplished the same comparison with other Egyptian strains gave the same conclusion (same protein content but with different concentrations of amino acids). Leucine in both unenrichment (17.22\%) and enrichment (14.8\%) $A$. tunisiana was above the minimum requirement of fish (Seidel et al. 1980) and also above its value in A. franciscana. Glycine (1.7\%) was lower than that recorded in other Egyptian Artemia strains (Abdel Rahman, 1995) or the herein A. franciscana (4.3\%), but this type of amino acid is non-essential, so in terms of protein quality $A$. tunisiana could be utilized as an adequate dietary protein source for cultured fish larvae.

Leger et al. (1985) and Leger et al. (1987) concluded that the main factor affecting the nutritional value of Artemia for marine shrimp larvae was the content of the highly unsaturated fatty acid (HUFA) eicosapentaenoic acid 20:5 n-3 (EPA). It was found that $\omega 3$ polyunsaturated fatty acids (PUFAs) are required for lobsters (Castell \& Covey, 1976), prawns (Guary, Kayama, Murakami, \& Ceccaldi, 1976; Kanazawa, Teshima, \& Ono, 1979), and several marine fish, including plaice (Owen, Adron, Sargent, \& Cowey, 1972), red sea bream (Yone \& Fujii, 1975a), and turbot (Cowey, Owen, Adron, \& Middeleton, 1976).

The present analysis showed a slight difference in lipid composition (\%) between examined strains except for Port Saied and San Francisco Bay strains. The total lipid of A. tunisiana, Borg El Arab, and El Mex strain $(\approx 12.59-14 \%)$ resembled another Artemia sp. (9-13\%) studied by Anh et al. (2009). Triantaphyllidis et al. (1995) and Han et al. (2000) established that the lipid composition of hatched nauplii is not affected by diet or environmental conditions. The differences in lipid profile that are observed between strains can reflect either genetic characteristic or the lipid profile of the food of the parental population. Several authors have demonstrated that the fatty acid profile of Artemia adults and their offspring clearly reflects the composition of the parental diet, despite the strain (Navarro \& Amat, 1992). It was stated that the essential fatty acids contained in Artemia nauplii are the principle value of Artemia to fish (Watanabe, Oowa, Kitajima, \& Fujita, 1978). Many publications include values for 15 or more different fatty acids in Artemia nauplii, but according to Leger et al. (1986) only six fatty acids $(16: 0,16: 1 \omega 7,18: 1 \omega 9,18: 2 \omega 6$, 18:3 n-3, and 20:5 n-3) actually make up about $80 \%$ of the total fatty acid pool in an Artemia sample. When calculating the ratio of these six fatty acids during this work, the result showed the same ratio with A. franciscana (77.5\%) and enriched Artemia tunisiana for 18 or $24 \mathrm{~h}$ ( 79.4 and $84.9 \%$ respectively) while this ratio differed in the case of unenrichment of A. tunisiana, it was $58.9 \%$. The same author compiled data in almost 150 fatty acid analyses of nauplii from about 20 different Artemia sources and came to the following conclusions. Oleic acid $(18: 1 \omega 9)$ is often the most abundant fatty acid. The present species (A. tunisiana) and the imported one (A. franciscana) recorded the high concentration of oleic acid (18:1 n9) comparable to other fatty acids, it scored $32.5,26.35,35.3$, and $35.85 \mathrm{mg} / \mathrm{g}$ DW for A. franciscana and $A$. tunisiana unenriched and enriched (18 and $24 \mathrm{~h}$ respectively). It also has the most stable occurrence. Together with palmitic (16:0), it accounts for $40-50 \%$ of the total fatty acids in Artemia. The level of 16:0 is fairly constant over different strains $(\approx 15 \%)$ as showed in the herein species; other studies recorded 13.2-19.4 mg/g DW in Great Salt Lake strain (Lavens et al., 1989), $12.6 \mathrm{mg} / \mathrm{g} \mathrm{DW}$ in PR China (Han et al., 2000), $15.7 \%$ in Artemia parthenogenitica (Triantaphyllidis et al., 1995), and $14.4 \mathrm{mg} / \mathrm{g}$ DW in A. persimilis (Han et al., 2000). The levels of EPA $(20: 5 \omega 3)$ seem to be inversely related to linolenic acid.

The concentration of EPA in freshly hatched nauplii of A. tunisiana was low $(1.3 \mathrm{mg} / \mathrm{g} \mathrm{DW})$ and lower than the tested $A$. franciscana ( $3.3 \mathrm{mg} / \mathrm{g} \mathrm{DW})$. The low concentration of EPA was observed also in Great Salt Lake (3. $5 \mathrm{mg} / \mathrm{g} \mathrm{DW}$ ), PR China (1.4 mg/g DW), and Urmia, Iran strain $(2.7 \mathrm{mg} / \mathrm{g} \mathrm{DW})$, A. persimilis (0.0) (García-Ortega et al. (1998); Dhert et al. (1993); Triantaphyllidis et al. (1995) and Han et al. (2000) respectively). Fujita et al. (1980) reported that marine fish require EPA and DHA in its diet while freshwater fish require linolenic acid $(18: 3 \mathrm{n}-3)$. Therefore, the local strain (A. tunisiana) in its original state is not an ideal food for larvae of marine fish and crustaceans so it is urgent to enrich it to improve the levels of these fatty acids to suit the feeding of marine creatures. Studies in Japan and the multidisciplinary International Study on Artemia revealed that the concentration of the essential fatty acid eicosapentaenoic (EPA) in Artemia nauplii was determining its nutritional value for larvae of various marine fishes and crustaceans (Leger et al., 1986). Beneficially, EPA (20:5 $\omega 3)$ was increased by enrichment from $1.3 \mathrm{mg} / \mathrm{g} \mathrm{DW}$ to six times its original concentration $(7.6 \mathrm{mg} / \mathrm{g} \mathrm{DW})$ after $18 \mathrm{~h}$, while no significant differences between 18 and $24 \mathrm{~h}$. Comparable with A. franciscana, EPA (3.3\%) is significantly lower than the enriched tunisiana. EPA was measured in other strains of $A$. franciscana by many authors and scored 4.4, 5.5, and 4.1\% (Dhert et al., 1993 and Estevez et al., 1998) while others scored high EPA contents 29.6-53\% (Han et al., 2000). Before enrichment, the local Egyptian Artemia (tunisiana) was classified into freshwater type according to Watanabe et al. (1978), which contain low levels of 20:5 n3, but after enrichment 
and the improvement of EPA ratio, it became suitable for the marine fish.

The ratio of DHA in freshly hatched Artemia tunisiana was 0.0; in addition, its value in the studied A franciscana was also low $(0.04 \mathrm{mg} / \mathrm{g} \mathrm{DW})$. The low ratio of DHA is explained by McEvoy et al. (1995) who publicized that Artemia converts docosahexaenoic acid (DHA) into EPA. The DHA, which was rarely found in the present strain, is known to promote survival and growth especially in crab cultures (Levin \& Sulkin, 1984; Leger et al., 1987). Takeuchi et al. (1994) suggested that the appropriate level of DHA should be around 1\% DW. In their study, any amount higher than 1\% DHA resulted in a high percentage of abnormal fish, together with high mortality. Taking advantage of the primitive feeding characteristics of Artemia nauplii, it is possible to manipulate the nutritional value of HUFA-deficient Artemia, because brine shrimp nauplii that have molted into the second instar stage (i.e., about $8 \mathrm{~h}$ following hatching) are non-selective particle feeders. A simple method had been developed to incorporate different kinds of products into the Artemia prior to feeding to predator larvae. So enrichment of the local strain (A. tunisiana) improved and corrected the value of DHA to be $1.45 \mathrm{mg} / \mathrm{g}$ DW after $18 \mathrm{~h}$ and $1.86 \mathrm{mg} / \mathrm{g}$ DW after $24 \mathrm{~h}$ from enrichment. Sargent et al. (1999) suggested that species-specific requirements for DHA exist among marine finfish larvae but several other studies suggested that much higher levels of DHA (or n-3 HUFAs) could reduce larval survival (Planas \& Cunha, 1999).

Copeman et al. (2002) found that yellow tail flounder fed high DHA/EPA (8:1) had a higher growth and survival than those fed a DHA/EPA ratio of 1.9:1. So many contradictions are postulated about the function, concentration, and mechanism of DHA. Estevez et al. (1999) and Furuita et al. (1999) recorded no significant difference in the growth of Japanese flounder and turbot larvae when they were fed with different dietary ratios of DHA and EPA.

Several studies have focused their attention on the importance of other nutrients such as vitamins (Merchie et al., 1997 and Halver, 2002). For example, vitamin C (ascorbic acid) is considered as an essential nutrient during larviculture (Lavens and Sorgeloos, 1996). Vitamin C is found as ascorbic acid 2-sulfate (AAS) in Artemia cyst, during the hatching process, the AAS is hydrolyzed into free ascorbic acid and become available to predators.

Fish treated with HUFA + vitamin C gained better growth and lower mortality value in fish indicated that ascorbic acid supplementation enhanced resistance to stress, temperature, and salinity (Merchie et al., 1995). Clarias gariepinus larvae fed ascorbate-supplemented diet exhibited significantly low mortality than those larvae fed an ascorbate-free diet (Merchie et al., 1995). Better growth was observed among tilapia fingerlings (Anadu, Anozie, \& Anthony, 1990) and plaice (Rosenlund, Joergenses, Waagboe, \& Sadnes, 1990) fed diets supplemented with ascorbic acid. Although it is possible that HUFA alone may have improved growth performance in trout (as reported in chonos chonos by Gapasin, Bombeo, Lavens, Sorgeloos, \& Nelis, 1998), the synergistic effect of vitamin $C$ cannot be neglected. The present Artemia enriched with HUFA + vitamin C to investigate its ability to increase its contents of ascorbic acid and to what extend was the rising of its level. The result showed good evidence to increase vitamin $C$ ratio by enrichment from 853 to $3227 \mu \mathrm{g} / \mathrm{g}$ dry weight.

The total energy values of the unenriched $A$. tunisiana $(23,270 \mathrm{~J} / \mathrm{g})$ was in close agreement with those of Paffenhofer (1967) who found a level of 24,900 J/g organic substance for an unidentified brine shrimp strain and with Vanhaecke et al. (1983) who recorded $23,250 \mathrm{~J} / \mathrm{g}$ with freshly hatched nauplii collected from various geographical origins. Enrichment elevated the energy content from $23,270 \mathrm{~J} / \mathrm{g}$ to 33,170 and $45,693 \mathrm{~J} / \mathrm{g}$ after 18 and $24 \mathrm{~h}$ of enrichment respectively. The nutritional effectiveness of a food organism is in the first place determined by its ingestibility and as a consequence by its size and form. So feasibility and duration of enrichment process should also be under consideration when preparing Artemia nauplii as a food. Enrichment for 18 and 24 h was tested to score the lowest duration for suitable enrichment with keeping the size as petite as possible. Generally, enrichment processes for Artemia nauplii significantly elevated the majority of the fatty acids found in the nauplii. Most notable is the elevations of C20:5 n-3 (EPA) as well as infusion of C22:6 n-3 (DHA). Both of these have been implicated to be essential for larval growth and development in a number of fish species (Watanabe, Kitajima, \& Fujita, 1983). The result indicated that $18 \mathrm{~h}$ enrichment achieved good and enough nutritional value compared to $24 \mathrm{~h}$. For $18 \mathrm{~h}$, the length of enriched nauplii was $\approx 0.5 \mathrm{ml}$ while after $24 \mathrm{~h}$ their lengths achieved $\approx 0.65 \mathrm{ml}$. The size is not critical for crustacean larvae, which can capture and tear apart food particles with their feeding appendages. For marine fish larvae that have a very small mouth and swallow their prey in one bite, the size of the nauplii is particularly critical.

\section{Conclusions}

Enrichment with cod liver oil and vitamin $\mathrm{C}$ obviously had a positive effect on the chemical composition of local Egyptian Artemia (A. tunisiana). 


\section{Abbreviations}

DHA: Docosahexaenoate; EPA: Eicosapentaenoate; FAO: Food and Agriculture Organization; HUFAs: Highly unsaturated fatty acids

\section{Availability of data and materials}

The datasets generated and analyzed during the current study are available from the corresponding author on reasonable request.

\section{Authors' contributions}

E-SR wrote the manuscript, contributed to the design of the study, and carried out the data analysis. FS coordinated the design of the study and was responsible for the execution of the experiment. ME-G helped to write the manuscript. FA-R contributed to the design of the study, contributed to the literature review, and critically revised the manuscript. Finally, MMM provided the idea for the study, coordinated the study, and critically revised the manuscript. All authors read and approved the final manuscript.

\section{Ethics approval and consent to participate}

Authors were asked to participate in a satisfaction survey on a voluntary basis. Participants were informed that this survey was part of a research project. This study was approved by the Social Science Ethical Committee of Faculty of Science, Tanta University \& Research and complied with the Egyptian Code of Conduct for Scientific Practice, National Institute of Research, Egypt.

\section{Competing interests}

The authors declare that they have no competing interests.

\section{Publisher's Note}

Springer Nature remains neutral with regard to jurisdictional claims in published maps and institutional affiliations.

\section{Author details}

'Zoology Department, Faculty of Science, Tanta University, Tanta, Egypt

${ }^{2}$ National Institutes of Oceanography and Fisheries, Alexandria, Egypt.

\section{Received: 18 May 2017 Accepted: 18 April 2018}

Published online: 04 May 2018

\section{References}

Abdel Rahman, S. H. (1993). Exploitation of Artemia populations in Egyptian salterns and salt lakes. Present status and future prospects, (p. 150). Alexandria: Final Report, Inst. Ocean. Fish.

Abdel Rahman, S. H. (1994). Successful inoculation of Artemia and production of cysts in man-made saltern in Egypt, (p. 20). Alexandria: Bull. Ins. Ocean. Fish.

Abdel Rahman, S. H. (1995). Characteristics and nutritive value of local and imported Artemia strains as food for fish larvae. J Egypt Ger Soc Zool, 16(D), 77-100.

Abdel Rahman, S. H., \& Abdel Razek, F. A. (1992). Artemia production from Salinas and salt lakes in Egypt, (p. 30). Alexandria: Progressive report presented to ElNasr saline company.

Anadu, D. L., Anozie, O. C., \& Anthony, A. D. (1990). Growth responses of Tilapia zillii fed diets containing various levels of ascorbic acid cobalt chloride. Aquaculture, 88, 329-336.

Anh, N.T.N., Hoa, N.V., Van Stappen, G., Sorgeloos, P. (2009). Effect of different supplemental feeds on proximate composition and Artemia biomass production in salt ponds. Aquaculture, 286, 217-225.

Association of Official Analytical Chemists (AOAC) (1990). Official methods of analysis of the Association of Official Analytical Chemists, 15th edn, (p. 1298). Arlington: Association of Official Analytical Chemists in; C.

Blackbum, S. (1978). Sample preparation and hydrolytic methods. In S. Blackbum (Ed.), Amino acid determination methods and techniques, (2nd ed., p. 272). New York, NY: Marcel Dekker Inc..

Bligh, E. G., Dyer, W. J. (1959). A rapid method of total lipid extraction and purification. Canadian journal of Biochemistry and Physiology, 37(8), 911-917.

Castell, J. D., \& Covey, J. F. (1976). Dietary lipid requirements of adult lobsters (Homarus ameri-canus M.E.). The Journal of Nutrition, 106, 1159-1165.

Claus, C., Benijts, F., Vandeputte, G., \& Gardner, W. (1979). The biochemical composition of the larvae of two strains of Artemia salina (L.) reared on two different algal foods. Journal of Experimental Marine Biology and Ecology, 36, 171-183.
Copeman, L. A., Parrish, C. C., Brown, J. A., \& Harel, M. (2002). Effects of docosahexaenoic, eicosapentaenoic and arachidonic acids on the early growth survival, lipid composition and pigmentation of yellowtail flounder (Limanda ferruginea): Live food enrichment experiment. Aquaculture, 210, 285-304.

Cowey, C. B., Owen, J. M., Adron, J. W., \& Middeleton, C. (1976). Studies on the nutrition of marine flatfish. The effect of different dietary acids on the growth and fatty acid composition of turbot (Scophthalmus maximus). The British Journal of Nutrition, 36, 479-486.

Dhert, P., Sorgeloos, P., \& Devresse, B. (1993). Contributions towards a specific DHA enrichment in the live food Brachionus plicatilis and Artemia sp. In H. Reinertsen, L. A. Dahle, L. Jorgensen, \& K. Tvinnereim (Eds.), Fish farming technology, (pp. 109-115). Rotterdam: Balkema.

Estevez, A., McEvoy, L. A., Bell, J. G., \& Sargent, J. R. (1998). Effects of temperature and starvation time on the pattern and rate of loss of essential fatty acids in Artemia nauplii previously enriched using arachidonic acid and eicosapentaenoic acid-rich emulsion. Aquaculture, 165, 295-311.

Estevez, A., McEvoy, L. A., Bell, J. G., \& Sargent, J. R. (1999). Growth, survival, lipid composition and pigmentation of turbot (Scophthalmus maximus) lanvae fed livepreyenriched in arachidonic and eicosapentaenoic acids. Aquaculture, 180, 321-343.

Fujita, S., Watanabe, T., Kitajima C. (1980). Nutritional quality of Artemia from different localities as a living feed for marine fish from the viewpoint of essential fatty acids. In The Brine Shrimp Artemia: Ecology, Culturing, and Use in Aquaculture (Edited by Persoone G., Sorgeloos P., Roels O. and Jaspers E.), Vol. 3, pp. 277-290. Universa Press, Belgium.

Furuita, H., Konishi, K., \& Takeuchi, T. (1999). Effect of different levels of eicosapentaenoic and docosahexaenoic acid in Artemia nauplii on growth, survival and salinity tolerance of larvae of the Japanese flounder, Paralichthys olivaceus. Aquaculture, 170, 59-69.

Gapasin, R. S. J., Bombeo, R., Lavens, P., Sorgeloos, P., \& Nelis, H. J. (1998). Enrichment of live food with essential fatty acids and vitamin C: Effect on milkfish (Chanos chanos) larval. Performance. Aquaculture, 162, 269-285.

García-Ortega, A., Verreth, J. A. J., Segner, H., Coutteau, P., Huisman, E. A., \& Sorgeloos, P. (1998). Biochemical and enzymatic characterization of decapsulated cysts and nauplii of the brine shrimp Artemia at different developmental stages. Aquaculture, 161, 501-514.

Goddard, S. (1992). Practical laboratory guide for fish and crustacean nutrition, (p. 84). St. John's: Aquaculture Unit, School of Fisheries, Marine Institute of Memorial University of Newfoundland.

Gozalbo, A., \& Amat, F. (1988). Composición bioquímica de biomasas silvestres de Artemia (Crustácea, Branchiopoda, Anostraca). Investigacion Pesquera, 52(3), 375-385.

Guary, J. C., Kayama, M., Murakami, Y., \& Ceccaldi, H. J. (1976). The effects of fatfree and compounded diets supplemented with various oils on moult, growth and fatty acid composition of prawn, Penaeus japonicus bate. Aquaculture, 7, 245-254.

Halver, J. E. (2002). The vitamins. In J. E. Halver, \& R. W. Hardy (Eds.), Fish nutrition, (pp. 61-141). San Diego, CA: Thirded Academic Press.

Han, K., Geurden, I., \& Sorgeloos, P. (2000). Enrichment strategies for Artemia using emulsions providing different levels of ny 3 highly unsaturated fatty acids. Aquaculture, 183, 335-347.

Heydari, M., \& Akbary, P. (2011). Enrichment of Artemia nauplii with essential fatty acids and vitamin C: Effect on rainbow trout (Oncorhynchus mykiss) larvae performance. IPCBEE, 22.

Kanazawa, A., Teshima, S. I., \& Ono, K. (1979). Relationship between fatty acid requirements of aquatic animals and the capacity for bioconversion of linolenic acid to highly unsaturated fatty acids. Comparative Biochemistry and Physiology, 63B, 295.

Lavens, P., Léger, P., \& Sorgeloos, P. (1989). Manipulation of the fatty acid profile in Artemia offspring produced in intensive culture systems. In N. De Pauw, E. Jaspers, H. Ackefors, \& N. Wilkins (Eds.), Aquaculture: A biotechnology in progress, (pp. 731-739). Bredene: European Aquaculture Society.

Lavens, P., Sorgeloos, P. (1996). Manual on the production and use of live food for aquaculture. FAO Tech. 361, 295.

Leger, P., Bengston, D. A., Simpson, K. L., \& Sorgeloos, P. (1986). The use and nutritional value of Artemia as a food source. Oceanography and Marine Biology, 24, 521-623.

Leger, P., Naessens-Foucquaert, E., \& Sorgeloos, P. (1987). International study on Artemia. XXXV. Techniques to manipulate the fatty acid profile in Artemia nauplii and the effect on its nutritional effectiveness for the marine crustacean Mysidopsis bahia (M.). In Artemia research and its applications, Vol. 3. Ecology, culturing, use in aquaculture, (pp. 411-424). 
Leger, P., Bieber, G., \& Sorgeloos, P. (1985). International study on Artemia XXXIII. Promising result rearing of Penaeus stylirostris using prepared diet as algae substitute and for Artemia enrichment. Journal of the World Marcult. Society, 16, 354-367.

Levin, D. M., \& Sulkin, S. D. (1984). Nutritional significance of long chain polyunsatured fatty acids to the zoeal development of the brachyuran crab, Eurypanopeus depressus (Smith). Journal of Experimental Marine Biology and Ecology, 81, 211-223.

Lubzens, E., Tandler, A., \& Minkoff, G. (1989). Rotifers as food in aquaculture. Hydrobiologia, 186(187), 387-400.

Maldonado-Montiel, T. D., \& Rodriguez-Canche, L. G. (2005). Biomass production and nutritional value of Artemia sp. (Anostraca: Artemiidae) in Campeche, Mexico. Review biological tropics. International Journal Tropical Biology, 53, 447-454 ISSN-0034-7744.

McEvoy, L. A., Navarro, J. C., Bell, J. G., \& Sargent, J. R. (1995). Autoxidation of oil emulsion during the Artemia enrichment process. Aquaculture, 134, 104-112.

Merchie, G., Lavens, P., Dhert, P., Dehasque, M., Nelis, H., Deleenheer, A., \& Sorgeloos, P. (1995). Variation of ascorbic acid content in different live food organisms. Aquaculture, 134, 325-337.

Merchie, G., Lavens, P., Verreth, J., Ollevier, F., Nelis, H., Deleeheer, A., et al. (1997). The effect of supplemental ascorbic acid I enriched live food for Clarias gariemus larvae of start feeding. Aquaculture, 151, 245-258

Moraiti-loannidou, M., Castritsi-Catharios, J., Miliou, H., \& Sorgeloos, P. (2009). Biochemical composition and digestive enzyme activity during naupliar development of Artemia spp from three solar saltworks in Greece. Aquaculture, 286, 259-265.

Navarro, J. C., \& Amat, F. (1992). Effect of algal diet on the fatty acid composition of brine shrimp. Artemia sp. Cysts. Aquaculture, 101, 223-227.

Owen, J. M., Adron, J. W., Sargent, J. R., \& Cowey, C. B. (1972). Studies on the nutrition of marine flat fish. The effect of dietary fatty acids on the tissue fatty acids of the plaice Pleuronectus platessa. Marine Biology, 13, 160-166.

Paffenhofer, G. A. (1967). Caloric content of larvae of the brine shrimp Artemia salina. Helgoländer Wissenschaftliche Meeresuntersuchungen, 16, 130-135.

Planas, M., \& Cunha, I. (1999). Larviculture of marine fish: Problems and perspectives. Aquaculture, 177, 171-190.

Robin, J., Le Milinaire, C., \& Stephan, G. (1987). Production of Artemia using mixed diets: Control of fatty acid contont for marine fish larvae culture. In P. Sorgeloos, D. A. Bengton, W. Decleir, \& E. Jaspers (Eds.), Artemia research and its applications. Vol. 3. Wetteren: Universa. Press.

Rosenlund, G., Joergenses, L., Waagboe, R., \& Sadnes, K. (1990). Effects of different dietary levels of ascorbic acid in plaice (Pleuronecies platessa L.). Comparative Biochemistry and Physiology., 96, 395-398.

Salma, D., Davoodi, R., Shamsaei, M., \& Kamali, A. (2013). Comparative effect of fairy shrimp and Artemia in the rearing of blue gourami, Trichogaster trichopterus, larvae. Annual Review \& Research in Biology, 3(2), 70-75.

Sargent, J. R., Bell, J. G., McEvoy, L. A., Tocher, D. R., \& Estévez, A. (1999). The essential fatty acid nutrition of developing fish, Proc. 3rd Symp (). Barcelona: On Research in Aquaculture.

Seidel, C.R., kryznowek, J., Simpson, K.L. (1980). International study on artemia. xi. amino acid composition and electrophoretic protein patterns of artemia from five geographical locations. In The brine shrimp artemia. val. 3. G. persoone, P. sorgeloos, O. roels and E. jaspers. Universa press, wetteren, 375-382.

Shahidi, F., Sunowiecki, J., \& Naczk, M. (1990). Seal meat—a potential source of muscle food: Chemical composition essential amino acids and color characteristics. Canadian Institute of Food Science and Technology Journal, 23, 1 37-1 39.

Sivaii, S. (2016). Evaluation of different feeds for the culture of Artemia parthenogenetica. Advance Research Journal of Medical and Clinical Sciences, 2(3), 8-14.

Sorgeloos, P., Dhert, P., Candreva, P. (2001): Use of the brine shrimp, Artemia spp., in marine fish aviculture. Aquaculture, 200, 147-159.

Takeuchi, T., Zheng, K., Yoseda, K., Hirokawa, J., \& Watanabe, T. (1994) Nutritive value of DHA-enriched rotifer for larval cod. Nihon-suisangakkai-shi, 60, 641-652.

Treece, G.D. (2000). Artemia production for marine larvae fish culture. SRAC publication NO. 702.

Triantaphyllidis, G. V., Poulopoulou, K., Abatzopoulos, T. J., Pinto Perez, C. A., \& Sorgeloos, P. (1995). International study on Artemia. XLIX. Salinity effects on survival, maturity, growth, biometrics, reproductive and life span characteristics of a bisexual and a parthenogenetic population of Artemia. Hydrobiologia, 302, 215-227.

Vanhaecke, P., Lavens P., Sorgeloos, P. (1983). International study on Artemia XVII. Energy consumption in cysts and early larval stages of various geographical strains of Artemia. Annales Societe Royale Zoologie de Belgique, 113, 155-164.
Van Stappen, G. (1996). Introduction, biology and ecology of Artemia. In P. Lavens, \& P. Sorgeloos (Eds.), Manual on the production and use of live food for aquaculture, Food and Agriculture Organization of the United Nations, (pp. 101-170).

Watanabe, T., Kitajima, C., \& Fujita, S. (1983). Nutritional values of live food organisms used in Japan for mass propagation of fish: A review. Aquaculture, 34, 115-143.

Watanabe, T., Oowa, F., Kitajima, C., \& Fujita, S. (1978). Nutritional quality of brine shrimp, Artemia salina, as a living feed from the viewpoint of essential fatty acids for fish. Bulletin of the Japanese Society of Scientific Fisheries, 44, 1115.

Yamanaka, H. (1989). Changes in polyamines and amino acids in scallop adductor muscle during storage. Journal of Food Science, 54, 1 133-1 135

Yone, Y., \& Fujii, M. (1975). Studies on nutrition of Red Sea Bream. XI. Effect of 3 fatty acid supplements in a corn oil diet on growth rate and feed efficiency. Bull Jap Soc Scient Fish., 41, 73-77.

Zaki, M. I., \& Abdel Rahman, S. H. (1985). The induced spawning of gilthead bream Sparus aurata and rearing of its larvae. Bull Inst Ocean Fish Are, 11, 119-129.

\section{Submit your manuscript to a SpringerOpen ${ }^{\mathcal{O}}$ journal and benefit from:}

- Convenient online submission

- Rigorous peer review

- Open access: articles freely available online

- High visibility within the field

- Retaining the copyright to your article

Submit your next manuscript at $>$ springeropen.com 